\title{
Treatment of milk wastewater using up-flow anaerobic packed bed reactor
}

\author{
Kiran D. Bhuyar ${ }^{1}$, Sanvidhan G. Suke ${ }^{2^{*}}$, S.D. Dawande ${ }^{3}$ \\ ${ }^{1}$ Department of Chemical Engineering, Priyadarshini Institute of Engineering and Technology, Nagpur- 440 019, India \\ ${ }^{2}$ Department of Biotechnology, Priyadarshini Institute of Engineering and Technology, Nagpur- 440 019, India \\ ${ }^{3}$ Department of Chemical Engineering, Laxminarayan Institute of Technology, RTM Nagpur University, Nagpur-440 033, \\ India \\ "Corresponding author: e-mail: sgsuke@hotmail.com
}

\begin{abstract}
An up-flow anaerobic packed bed (UAPB) bioreactor has been designed on a laboratory-scale and used for treatment of domestic milk wastewater (MWW). The UAPB bioreactor was operated under mesophilic temperature $\left(37-45^{\circ} \mathrm{C}\right)$ and reactor performance evaluated at various organic loading rates of MWW effluent at hydraulic retention times (HRT) of 1, 2, and $3 \mathrm{~d}$ based on the removal of organic matter COD, BOD, SS, pH changes and biogas production. The kinetic parameters were estimated using the experimental data to develop a reactor model. Empirical relations were generated for the characteristics like COD, BOD, and SS using modeling equations. This study proved that the UAPB reactor performance is excellent for treating domestic MWW and easily biodegradable dairy wastewater influent. Hence, this system can operate at low costs, making it suited for use in the developing countries and rural areas.
\end{abstract}

Keywords: Up-flow anaerobic packed-bed reactor, Milk wastewater, Kinetic parameters, Hydraulic retention times, Biogas.

\section{INTRODUCTION}

Ever increasing population and rapid urbanization considerably increased the rate of water pollution. The dwindling supplies of natural resources of water have made a serious constraint for population, industrial growth and for a reasonable standard of urban living. The environmental protection agencies imposed more stringent regulatory prohibitions and they have started more strict vigil along with some non governmental organizations to protect the environment. Nagpur is the most developing city of central India, and due to rapid urbanization and uncontrolled growth rate of population, increased a hotels, restaurants, coffee houses and road side local tea canteens. The source of wastewaters is from domestic and industrial activities. Coffee houses and road side tea canteens used milk and fresh water for preparation of tea or coffee and frequently discharge their wastes directly to close surroundings, generating environmental nuisances.

Wastewater contains number of pathogenic, microorganisms and nutrients which can affect the human and the environment ${ }^{1}$. Milk wastewater (MWW) usually contains high concentrations of organic matter, solids, and some dissolved inorganic pollutants ${ }^{2-4}$. However, it has high concentration of dissolved organic components like whey proteins, lactose, fat and minerals and it is also malodorous because of decomposition of some of the contaminants causing discomfort to surrounding population $^{5,6}$. In these reasons, treatment of wastewater is of utmost important and treated wastewater can be used as an alternative source to fresh water.

The energy water nexus can be positively affected by treating wastewater and recycling it to reduce fresh water demand. That has been made wastewater treatment more expensive and to comply with the discharge quality standard itself. It was therefore felt that the possibilities of reuse of the wastewater for various purposes should be investigated. The recycling or reuse of water for similar duties mainly depends on availability of suitable process technology for water purification ${ }^{7}$. There is tremendous need to develop reliable technologies for the treatment of domestic wastewater in developing countries. Such treatment systems must fulfill many requirements, such as simple design, use of non-sophisticated equipment, high treatment efficiency, and low operating and capital costs $^{8}$. In addition, consonant with population growth and increase in urbanization, the cost and availability of land is becoming a limiting factor, and footprint size is increasingly becoming important in the choice of a treatment system.

Anaerobic technologies should be considered for domestic wastewater treatment as an alternative to more conventional aerobic technologies in most developing countries for a variety of reasons. Anaerobic technologies already have been applied successfully for treatment of a number of waste streams, including low strength wastewaters such as domestic wastewater, particularly under tropical conditions, ${ }^{9}$. Anaerobic treatment can be carried out with technically simple setups, at any scale and almost any place. The drawback of such treatment would be accompanied with mal-odorous nuisance problem. It produces a small amount of excess, well stabilized sludge, and energy can be recovered in the form of biogas. The process can be carried out in both centralized and decentralized modes, and the latter application can lead to significant savings in investment costs of sewerage systems ${ }^{11,12}$. However, while anaerobic processes have gained popularity over the past decade, skepticism related to their application for domestic wastewater treatment remains widespread ${ }^{13-15}$.

The objective of the present study was to enhance the anaerobic treatment of domestic milk wastewater influent in up-flow anaerobic packed bed (UAPB) reactor and studied the influence of hydraulic retention time (HRT) on operational parameters, COD (chemical oxygen demand), BOD (biological oxygen demand), SS (suspended solids), $\mathrm{pH}$ changes and biogas production rate were investigated and high treatment of domestic wastewater effluent from coffee houses and tea canteens has been 
achieved. The kinetic parameters were also estimated using the experimental data to develop a reactor model.

\section{EXPERIMENTAL}

Milk wastewaters were collected every day, between 7:00 and 11:00 $\mathrm{h}$ in the morning from local canteens (road side coffee shops and tea stalls) located various places of Nagpur city. MWW was pumped just below the water surface using a mini submersible pump (Mach Powerpoint Pumps India Pvt. Ltd., India) immediately after the screens and grit chamber, and stored in tightly closed $1 \mathrm{~L}$ containers at $4^{\circ} \mathrm{C}$. The characteristics MWW were determined.

A laboratory scale anaerobic experimental setup of an up-flow anaerobic packed bed reactor (UAPBR) used for MWW treatment shown in Figure 1. The UAPBR was fabricated using PVC pipes and fittings with an internal diameter of $16 \mathrm{~cm}$ and a height of $90 \mathrm{~cm}$. The reactor was randomly packed with pieces of corrugated PVC plastic rings. The total volume of the reactor was $16 \mathrm{~L}$ including packed $1.5 \mathrm{~L}$ and $14.5 \mathrm{~L}$ volume for working liquid phase. Reactor contains four ports with heights at $17 \mathrm{~cm}, 38 \mathrm{~cm}, 57 \mathrm{~cm}$ and $74 \mathrm{~cm}$ from the bottom of reactor. The experiment was performed at room temperature and reactor was operated during the months of March to June (summer season) the natural reactor temperature was $37-45^{\circ} \mathrm{C}$. The inlet for $\mathrm{MWW}$ influent provided at bottom of the reactor and outlet for MWW effluent collection only first port from top of the reactor was used. An outlet also provided on top of the reactor for collection of gas.

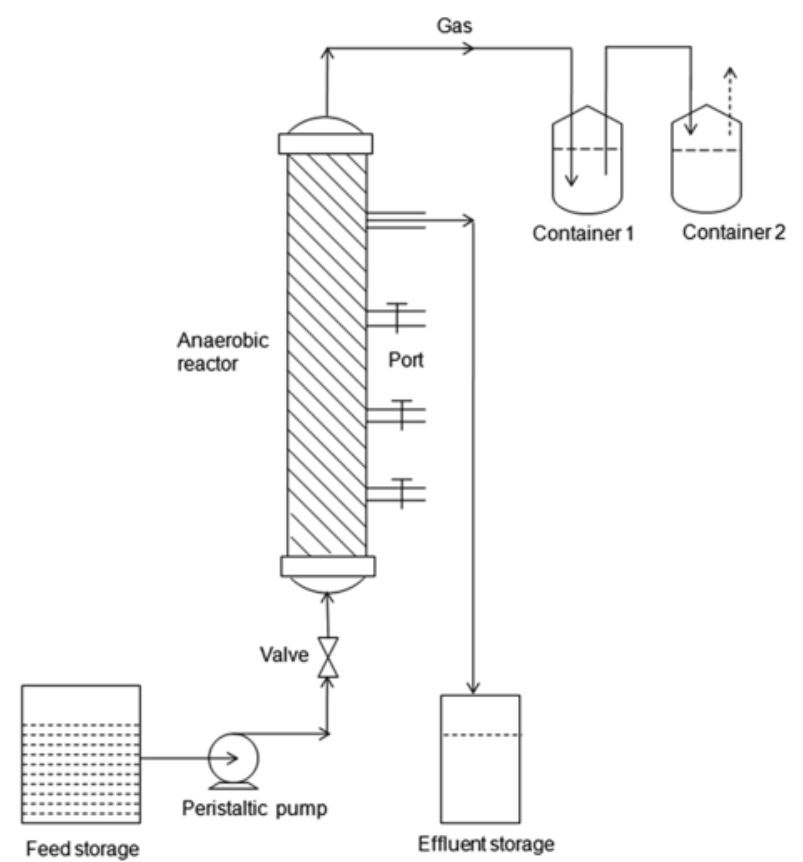

Figure 1. Schematic diagram of Up-flow anaerobic packed bed reactor (UAPBR)

The UAPB reactor provided higher surface area per unit volume. A trap has been provided at an outlet which serves following purposes. The reactor was operated at mesophilic temperature $37-45^{\circ} \mathrm{C}$. It was seeded with $750 \mathrm{ml}$ of granular anaerobic sludge culture obtained from milk processing plant (Amul dairy, India) containing $200 \mathrm{ml}$ nutrient solution, $500 \mathrm{ml}$ synthetic milk waste and $50 \mathrm{ml}$ of sewage. The reactor was first completely filled with collected MWW and allows to kept stand for about two weeks, and biological growth occurred inside the reactor. Then the reactor was fed with the diluted MWW influent starting with a detention time of 1 days which was gradually increased up to 3 days and the pilot was operated at a hydraulic retention time (HRT) [reactor volume (L) divided by the volume of treated water per hours $(\mathrm{L} / \mathrm{h})]$ of $24 \mathrm{~h}$. Influent flow rates were kept constant as $0.58 \mathrm{~L} / \mathrm{h}, 0.29 \mathrm{~L} / \mathrm{h}, 0.19 \mathrm{~L} / \mathrm{h}$ for HRT of 24,48 and 72 hours $(1,2$ and 3 d) respectively. Organic loading rates (OLR) were observed 1.5, 0.75, 0.5 ( $\mathrm{g} \mathrm{COD} / \mathrm{L}$ day) at HRT of 1, 2, 3 days respectively. At the top of the reactor two calibrated glass bottles of volume $5 \mathrm{~L}$ were used to collect and measure the volume of gas generated per day. The volume of biogas determined daily by the water displacement method. Generated gas was displaced water from one bottle to another bottle and quantity of displaced water in the glass bottles were considered as volume of gas produced ${ }^{\mathbf{1 6}}$. Gas volume was recorded with respect to constant HRTs. Effluents were collected in the $5 \mathrm{~L}$ plastic container placed at the ground level of the reactor and connected to outlet (first port) of the reactor. Changes of $\mathrm{pH}$ were recorded by using Systronic, India $\mathrm{pH}$ meter.

Regular analysis were performed on samples for the influent and effluent of the reactor which included (chemical oxygen demand) COD, (biological oxygen demand) BOD and suspended solids (SS) using procedures outlined in standard methods ${ }^{17}$. Collected sewage for the study diluted with plane water to make the concentrations of COD, BOD and SS constant throughout the study and the reactor was fed with a real diluted effluent. However, kinetic studies on MWW using UAPBR were performed. The experimental observations and their kinetic interpretation were used to evaluate the substrate utilization (COD removal) kinetics of the anaerobic process of treatment having attached growth system $^{18}$. The general mathematical expression that relates organic loading rate $(B v, \mathrm{~g} C O D / L)$ and removal efficiency was given by the equation $\mathrm{E}=K_{1}[\ln (1 / B v)]$ $+K_{2}$, where $\mathrm{E}$ is the removal efficiency at a given value of $B v, K_{1}$ is a dimensionless empirical constant and $K_{2}$ is another empirical constant equivalent to the $\mathrm{E}$ value obtained when OLR is equal to unity and, therefore, $\ln (1 / B v)$ is equal to zero. All mathematical calculations were implemented using Microsoft Office Excel 2007.

\section{RESULTS AND DISCUSSION}

The characteristics of MWW samples are shown in the Tables 1 . In order to determine the analytical parameters of MWW during UAPB reactor treatment, $1500 \mathrm{mg} / \mathrm{L}$ of COD, $900 \mathrm{mg} / \mathrm{L}$ of BOD, $1000 \mathrm{mg} / \mathrm{L}$ of SS and $\mathrm{pH}$ 7.2 of diluted influent were maintain throughout the

Table 1. Characteristics of the domestic milk wastewater

\begin{tabular}{|l|c|}
\hline Parameters & Observation \\
\hline Color & Milky brown \\
\hline $\mathrm{pH}$ & $7.2-9.5$ \\
\hline Chemical oxygen demand [COD], mg/L & $1500-3500$ \\
\hline Biological oxygen demand [BOD], mg/L & $900-2700$ \\
\hline Suspended solids [SS], mg/L & $830-1860$ \\
\hline Alkalinity [mg/L CaCO & $664-261$ \\
\hline
\end{tabular}


experiment and effluent parameters values were significantly change with respective to time in days (HRT). The reactor was run on continuous mode up to three days without interruption, and effluents were collected three times in a day for analysis of different parameters after completion of 24, 48 and $72 \mathrm{~h}$ and results are presented in the average form in Table 2. Previous report shows that biological treatment of dairy wastewater by sequencing batch reactor; the elimination of COD increased with the time up to $6 \mathrm{~h}$, more than $90 \%$ COD removal efficiency was achieved in the reactor with influent $\mathrm{COD}^{19}$.

Table 2. Effect on analytical parameters by treatment of domestic MWW using UAPBR

\begin{tabular}{|l|c|c|c|c|}
\hline Day & \multicolumn{4}{|c|}{ Effluent parameters } \\
[Mean \pm Standard deviation] \\
\hline $\begin{array}{l}\text { HRT } \\
\text { [d] }\end{array}$ & COD [mg/L] & BOD [mg/L] & SS [mg/L] & $\mathrm{pH}$ \\
\hline 1. & $565 \pm 162.04$ & $305 \pm 139.24$ & $247 \pm 112.48$ & $4.4 \pm 0.152$ \\
\hline 2. & $425 \pm 124.70$ & $211 \pm 137.65$ & $155 \pm 105.67$ & $4.2 \pm 0.116$ \\
\hline 3. & $248 \pm 114.33$ & $163 \pm 128.24$ & $58 \pm 43.30$ & $4.2 \pm 0.071$ \\
\hline
\end{tabular}

In the present study reactor was started with an initial OLR of $1.5 \mathrm{~g} \mathrm{COD} / \mathrm{L}$ d (i.e. feed concentration of COD $1500 \mathrm{mg} / \mathrm{L}$ ) at a HRT of $1 \mathrm{~d}$. Then the reactor loadings were decreased stepwise $1.5,0.75$, and $0.5 \mathrm{~g} \mathrm{COD} / \mathrm{L} \mathrm{d}$ with increased in HRT from 1 to $3 \mathrm{~d}$ and decreased flow rate of influent. The results indicated that as HRT enhanced from 24 to $72 \mathrm{~h}$ ( 1 to $3 \mathrm{~d}$ ), there was increased in COD reduction efficiency of the reactor performance, similarly concentration of effluent BOD and SS reduction efficiency increased with increase in HRT (Fig. 2). Treatment of MWW in the UAPB reactor, results obtained removal efficiency of COD were $62.32,71.66$, and $83.42 \%$ at HRT 1,2 and $3 \mathrm{~d}$ respectively. The COD effluent was reduced up to $248 \mathrm{mg} / \mathrm{L}$ for MWW. Previous reports shows that COD removal efficiency increased with increasing HRT, when HRT increased from 36 to $48 \mathrm{~h}$, the COD removal efficiency increased from 88 to $97.5 \%{ }^{20}$. The influent BOD concentration of MWW (900 mg/L) was considerably reduced to $163 \mathrm{mg} / \mathrm{L}$ and removal efficiency of BOD were noted to be $66.11 \%$ at HRT $1 \mathrm{~d}$ and $76.55 \%, 81.88 \%$ at HRT $2 \mathrm{~d}$ and $3 \mathrm{~d}$ respectively. However, the initial SS concentration of MWW $(1000 \mathrm{mg} / \mathrm{L})$ was considerably reduced to $58 \mathrm{mg} / \mathrm{L}$ and SS removal efficiency were recorded $75.24 \%$ at HRT $1 \mathrm{~d}$ and 84.55,

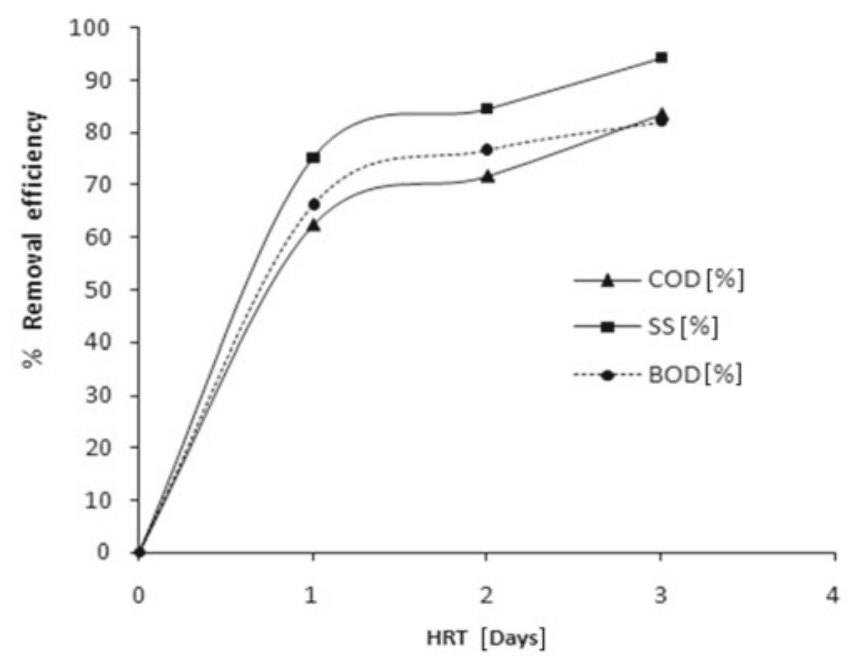

Figure 2. Influence of HRT on COD, BOD and SS percentage removal efficiency
$94.23 \%$ at HRT 2d and 3d respectively. Earlier report also indicated that as HRT increased 6, 12, 18 and $24 \mathrm{~h}$ then SS reduction efficiency were also increased 82.89, 83.86, 81.2 and $87.4 \%$ respectively ${ }^{21}$. From the present study results evident that the UAPBR was a suitable for MWW treatment. The biochemical parameters removal efficiency were enhanced with increasing HRT, the best sludge setting properties for the MWW were obtained at $3 \mathrm{~d}$ HRT are aerated period of 72 hours.

The most important process control parameters for anaerobic treatment are $\mathrm{pH}$ and alkalinity ${ }^{22}$. In the present study, the $\mathrm{pH}$ of the raw MWW in range 7.2-9.2 and it adjusted during treatment to $\mathrm{pH}$ 7.2. Table 2 shows that the $\mathrm{pH}$ of the MWW effluent varying between $\mathrm{pH}$ 4.2 to 4.4 at HRT. The low $\mathrm{pH}$ value indicated that acid production occurred inside the reactor and that was requires a proper attention in further studies on the reactor. Previous study laboratory-scale experiments were carried out to evaluate the effect of initial acidification of feedstock consisting of different components on biogas production and composition, the results showed that acidification increased the biogas production in the bioreactor ${ }^{23}$. In the present result the $\mathrm{pH}$ of the effluent a low value and this may be due to a longer detention time being provided to the MWW. In order to the $\mathrm{pH}$ may remain well within the acceptable limit. It was necessary that two stages of anaerobic degradation such as acidification and methanogenesis reactors were separated and as a remedial measure to that, with a smaller detention time so that acidification should not occur beyond control and the gas production obtained. In this context, domestic MWW on gas generation was conducted and nature of curve gradually increased (Fig. 3). It was observed that, as HRT increased, the gas production rate also increased. It was mainly due to decreased loading and increased activity of the biomass. However at each change of loading rates, marginal increased in gas production rate was observed. Maximum biogas of $0.59 \mathrm{~L} \mathrm{~d}$ was obtained at an OLR of $0.5 \mathrm{~g} \mathrm{COD} / \mathrm{L}$ d. This is due to fact that more COD was satisfied with the increased HRT. The maximum gas production at HRT 2 and 3 $\mathrm{d}$ were 0.50 and $0.59 \mathrm{~L} / \mathrm{d} \mathrm{L}$ respectively and minimum value around $0.40 \mathrm{~L} / \mathrm{d} \mathrm{L}$ at HRT $1 \mathrm{~d}$. The actual gas production was measured only about 59\% at 3d HRT during the experiment; this may be due to increased in $\mathrm{pH}$ in the reactor. Earlier reports shows that in the acidic environment, methanogenesis unable to work properly and production of gas was less, 300 and $380 \mathrm{ml} / \mathrm{h}$ gas produced at HRT 30 and $40 \mathrm{~h}$ respectively ${ }^{24}$. However, anaerobic treatment of dairy wastewater shows that biogas production rate and COD removal efficiencies were increased with an increased in operating periods, it was observed that there was decreased in COD reduction whenever the OLRs increased. It can be attributed to the fact that an increased in OLR was obtained by an increased in feed concentration, which inhibited very sensitive methanogenic bacteria temporarily. In comparison with other previously reported study based on different configuration of the system and operation at different geographical conditions that results difference may vary.

The success of any biological treatment plant lies in kinetics of the process as they determine the dimensions of the unit operation and dictates the control parameters 
and operating values. The experimental observations and their kinetics interpretation were used to evaluate the substrate utilization (COD removal) kinetics of the anaerobic process of treatment having attached growth system $^{18}$. Removal of COD was envisaged for the maximum percentage, with necessary operating variables of influent $\mathrm{COD}, \mathrm{SS}, \mathrm{pH}$, biogas and HRT. The loading rate of organics on the biological system, the composition of biological systems and the active status of the biological systems were correlated to explain the process of COD removal ${ }^{25}$. Better utilization of organics by the biological system for their energy requirement (during which they also stabilize most of the unstabilized waste constituents) better the COD removal.

According to the results obtained by regression analysis, logarithmic type functions appear to describe the effect of $B v$ on the removal efficiency ${ }^{26}$. The results obtained by using above general mathematical equation. The values for the empirical constants $K_{1}$ and $K_{2}$ obtained in the experiment and the correlation factors were summarized in Table 3. The above mathematical model only valid within the experimental range of $B v$ studied. An decreased of $B v 1.5,0.75$ and $0.5 \mathrm{~g} \mathrm{COD} / \mathrm{L} \mathrm{d}$ caused virtually a linear increased in the removal efficiency of COD 62.32, 71.66 and $83.42 \%$ respectively. When $B v$ increased from 0.5 to $1.5 \mathrm{~g} \mathrm{COD} / \mathrm{L} \mathrm{d}$, the effluent COD concentration increased moderately from 248 to $565 \mathrm{mg} / \mathrm{L}$. Hence, the process was capable of assimilating a considerable increased of the organic loading without failure. The following empirical relationship was found between $B v$ and effluent COD $(E$ COD $)=19.105 B \mathrm{v}+89.979$. The BOD levels decreased at a satisfactory rate. The removal efficiency equations for BOD was obtained as $E$ BOD $=15.343 B v+88.911$. Likewise, empirical relations were developed for SS parameter whose percentage of removal efficiency decreased with increased of $B v$. The rate of removal efficiencies of SS proceeded at a slower pace, the removal efficiency equations for SS was obtained as $E \mathrm{SS}=17.488 B v+100.71$. The plots of drawn curves are shown in the Figure 4 of loading rate $B v$ versus the

Table 3. The empirical constant $\mathrm{K}_{1}$ and $\mathrm{K}_{2}$, and the regression coefficients $\mathrm{R}^{2}$ of parameters $\mathrm{COD}, \mathrm{BOD}$ and $\mathrm{SS}$

\begin{tabular}{|l|c|c|c|}
\hline Parameters & $\mathrm{K}_{1}$ & $\mathrm{~K}_{2}$ & $\mathrm{R}^{2}$ \\
\hline COD & 19.105 & 89.979 & 0.8842 \\
\hline BOD & 15.343 & 88.911 & 0.9908 \\
\hline SS & 17.488 & 100.71 & 0.9166 \\
\hline
\end{tabular}

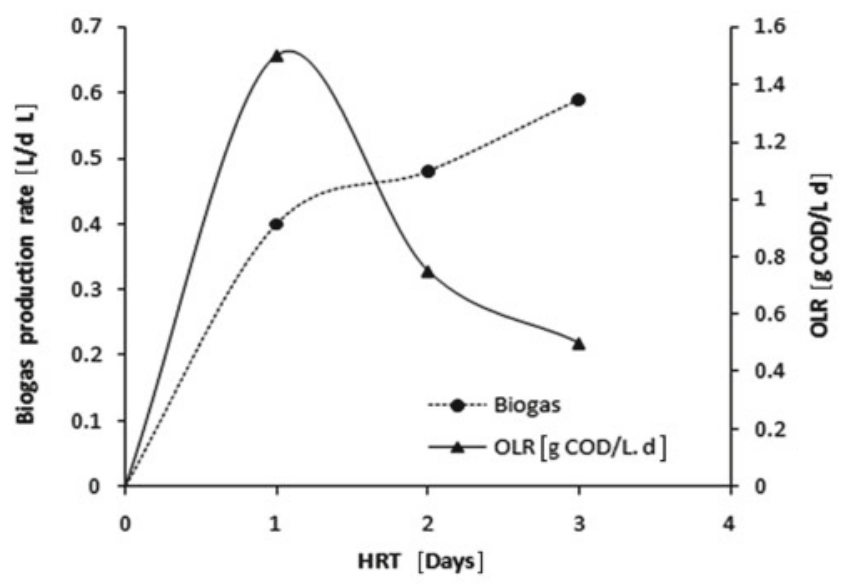

Figure 3. Influence of HRT on biogas production rate percentage removal efficiency is made to study the COD, BOD and SS parameter.

(A)

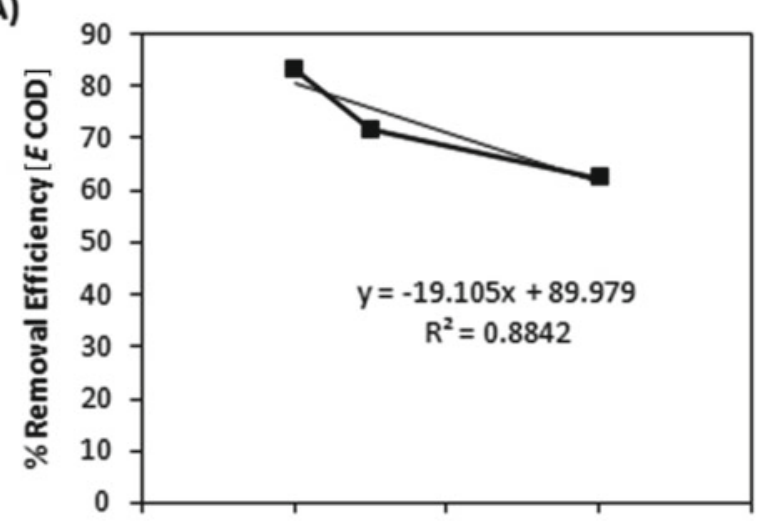

(B)
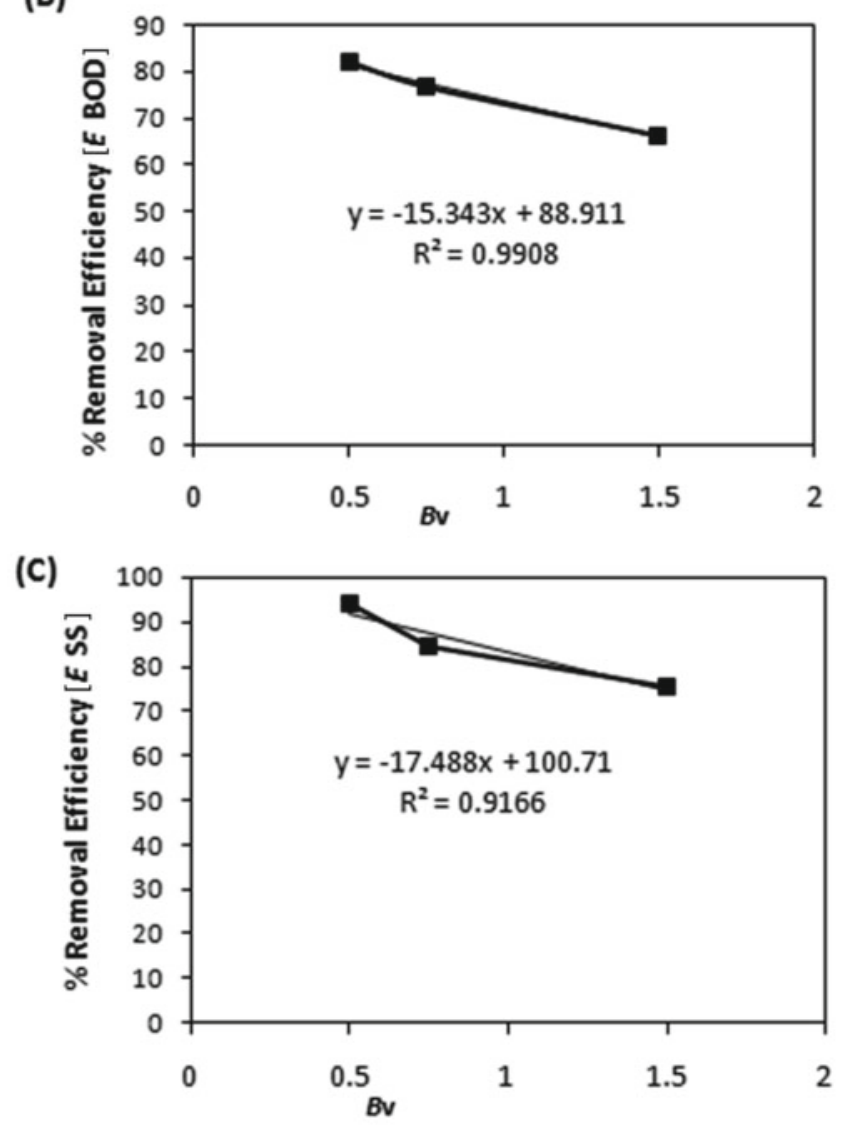

Figure 4. Removal efficiency graphs of (A) Bv vs \% COD, (B) $\mathrm{Bv}$ vs $\% \mathrm{BOD}$ and (C) $\mathrm{Bv}$ vs $\% \mathrm{SS}$

\section{CONCLUSIONS}

This study reveals that treatability of domestic MWW and investigated the influence of various HRTs on COD, $\mathrm{BOD}, \mathrm{SS}, \mathrm{pH}$ changes and biogas production rate in the UAPBR. The UAPB bioreactor was given a high performance and achieved a treatment goal successfully. The results showed that by increasing the HRTs, the treatment of influent was more effective with gradual increased in percentage COD, BOD and SS removal and also increased in biogas production rate. At HRT $3 \mathrm{~d}$, the COD, BOD and SS removal of 248, 163 and $58 \mathrm{mg} / \mathrm{L}$ respectively and removal efficiency were achieved 83.42, 81.88 and $94.25 \%$ respectively. The empirical equations for removal efficiencies of other characteristics were developed. Hence, the results from this study proved 
that the UAPB reactor performance is excellent for treating domestic MWW and easily biodegradable dairy wastewater influence. Furthermore, this system suited for use in the developing countries and rural areas for the treatment of MWW.

\section{ACKNOWLEDGMENTS}

The authors would like to thanks Department of Chemical Engineering, Laxminarayan Institute of Technology (RTM Nagpur University) Nagpur for scientific support throughout this study.

\section{LITERATURE CITED}

1. Al-Saadi, A., Raut, N., Talebi, S., Al-Darmaki, A. \& Al-Barwani, T. (2012). Wastewater Management for Sustainable Development. In: Proceedings of the World Congress on Engineering, Vol III WCE 2012, July 4-6, 2012, London, UK.

2. Deshannavar, U.B., Basavaraj, R.K. \& Naik, N.M. (2012). High rate digestion of dairy industry effluent by upflow anaerobic fixed-bed reactor. J. Chem. Pharma. Res. 4, 2895-2899. 3. Tawfik, A., Sobhey, M. \& Badawy, M. (2008). Treatment of a combined dairy and domestic wastewater in an up-flow anaerobic sludge blanket (UASB) reactor followed by activated sludge (AS system). Desalination 227, 167-177. DOI:10.1016/j. desal.2007.06.023.

4. Vourch, M., Balannec, B., Chaufer, B. \& Dorange, G. (2008). Treatment of dairy industry wastewater by reverse osmosis for water reuse. Desalination 219, 190-202. DOI:10.1016/j. desal.2007.05.013.

5. Kushwaha, J.P., Srivastava, V.C. \& Mall, I.D. (2011). An Overview of Various Technologies for the Treatment of Dairy Wastewaters. Crit. Rev. Food. Sci. Nutr. 51, 442-452. DOI: 10.1080/10408391003663879.

6. Sarkar, B., Chakrabarti, P.P., Vijaykumar, A. \& Kale, V. (2006). Wastewater treatment in dairy industries possibility of reuse. Desalination 195, 141-152. DOI:10.1016/j. desal.2005.11.015.

7. Aiyuka, S., Amoakoa, J., Raskinb, L., van Haandelc, A. \& Verstraete, W. (2004). Removal of carbon and nutrients from domestic wastewater using a low investment, integrated treatment concept. Water Res. 38, 3031-3042.

8. Zurita, F., Roy, E.D. \& White, J.R. (2012). Municipal wastewater treatment in Mexico: current status and opportunities for employing ecological treatment systems. Environ Technol. 33, 1151-8.

9. Latif, M.A., Ghufran, R., Wahid, Z.A. \& Ahmad, A. (2011). Integrated application of upflow anaerobic sludge blanket reactor for the treatment of wastewaters. Water Res. 45, 4683-99. DOI: 10.1016/j.watres.2011.05.049.

10. Chen, H., Yan, S.H., Ye, Z.L., Meng, H.J. \& Zhu, Y.G. (2012). Utilization of urban sewage sludge: Chinese perspectives. Environ. Sci. Pollut. Res. Int. 19, 1454-63. DOI: 10.1007/ s11356-012-0760-0.

11. Li, X., Guo, L., Yang, Q., Zeng, G. \& Liao, D. (2007) Removal of carbon and nutrients from low strength domestic wastewater by expanded granular sludge bed-zeolite bed filtration (EGSB-ZBF) integrated treatment concept. Process Biochem. 42, 1173-79. DOI:10.1016/j.procbio.2007.04.001.

12. Leitão, R.C., Santaellla, S.T., van Haandel, A.C., Zeeman, G. \& Lettinga, G. (2011). The effect of operational conditions on the hydrodynamic characteristics of the sludge bed in UASB reactors. Water Sci. Technol. 64, 1935-41. DOI: 10.2166/wst.2011.628.

13. Garcia, M.L., Lapa, K.R., Foresti, E. \& Zaiat, M. (2008). Effects of bed materials on the performance of an anaerobic sequencing batch biofilm reactor treating domestic sewage. J Environ Manage. 88, 1471-7. DOI: 10.1016/j.jenvman.2007.07.015.
14. Ngai, T.K., Shrestha, R.R., Dangol, B., Maharjan, M. \& Murcott, S.E. (2007). Design for sustainable development-household drinking water filter for arsenic and pathogen treatment in Nepal. J. Environ. Sci. Health A Tox Hazard Subst Environ Eng. 42, 1879-88.

15. Xu, J., Lee, J.H., Yin, K., Liu, H. \& Harrison, P.J. (2011). Environmental response to sewage treatment strategies: Hong Kong's experience in long term water quality monitoring. Mar. Pollut Bull. 62, 2275-87. DOI: 10.1016/j.marpolbul.2011.07.020. 16. Haydar, S. \& Aziz, J.A. (2009). Characterization and treatability studies of tannery wastewater using chemically enhanced primary treatment (CEPT) - a case study of Saddiq Leather Works. J. Hazard Mater. 163, 1076-83. DOI: 10.1016/j. jhazmat.2008.07.074

17. American Public Health Association (APHA). (1995). Standard methods for the examination of water and wastewater. American Public Health Association, American Water Works Association, and Water Pollution Control Federation. 19th edition, Washington, DC.

18. Husain, A. (1998). Mathematical Models of the Kinetics of Anaerobic Digestion - Selected Review. Biomass Bioenerg. 14, 561-571.

19. Mohseni-Bandpi, A. \& Bazari, H. (2004). Biological treatment of dairy wastewater by sequencing batch reactor. Iran J. Env. Health. Sci. Eng. 1.1, 65-69.

20. Najafpour, S., Alkarkhi, A.F.M., Kadir, M.O.A. \& Najafpour, G.D. (2008). Evaluation of spatial and temporal variation in river water quality. Int. J. Environ. Res. 2, 349-358.

21. Mahvi, A.H., Mesdaghinia, A.R. \& Saeedi, R. (2007). Upgrading an Existing Wastewater Treatment Plant Based on an Upflow Packed Bed Reactor. Iran J. Env. Health. Sci. Engg. 4, 229-234.

22. Kheradmand, S., Karimi-Jashni, A. \& Sartaj, M. (2010). Treatment of municipal landfill leachate using a combined anaerobic digester and activated sludge system. Waste Manag. 30, 1025-31. DOI: 10.1016/j.wasman.2010.01.021.

23. Dirnena, I., Dimanta, I., Gruduls, A., Kleperis, J., Elferts, D. \& Nikolajeva, V. (2013). Influence of the initial acidification step on biogas production and composition. Biotechnol Appl Biochem. 10.1002/bab.1163. DOI: 10.1002/bab.1163.

24. Ezeonu, F. \& Okaka, A. (1996). Process Kinetics and Digestion Efficiency of Anaerobic Batch Fermentation of Brewer's Spent Grains. Process Biochem. 31, 7-12.

25. Khademi, M., Najafpour, G.D., Navaei Nia, B., et al. (2009). Biological Treatment of antibiotic Plant Effluent in an UASFF Bioreactor. World App. J. Sci. Env. 5, 1-8.

26. Orhon, D., Gorgum, E., Germirli, F. \& Artan, N. (1993). Biological tretability of dairy wastewaters. Water Res. 27, 635-633. 